\title{
America: With Liberty and Justice For All and Other Myths and Fairy Tales Little Rock Reed
}

At the heart of justice is a divine spirit. It sprouts from the same seeds as life itself. And although we can define neither life nor justice, we are able to recognize injustice, the supreme form of which is to surrender to the status quo and to sanctify the myths and fantasies that breed it, among which is the national legend that in America there is liberty and justice for all. (Gerry Spence 1989)

The mythical quality of the legend that in America there is liberty and justice for all is illustrated in the results of a survey I conducted over a four-year period (Reed, et al., in press) in which the indictments of 612 convicted felons in Ohio's prison system were examined in cases where the prisoners had pled either 'guilty' or 'no contest' to the charges for which they were ultimately sent to prison. Before I reveal the results of the survey, I will present my own case study, as I am one of those 612 prisoners and, according to the results of the survey, my case is characteristic of the overwhelming majority of cases in which the defendant pleads 'guilty' or 'no contest.'

I committed an armed robbery of a drug store in the city of Cleveland. I took measures to see that no one would get hurt in the robbery and, in fact, no one was hurt. I took the money from the store, and I took several types of drugs, all of which were listed on a piece of paper I had brought into the store with me, and each of which I placed into a paper bag that I also brought into the store. After the robbery, each of the people who had been in the store during the robbery told the police and the news reporters that I was very mild-mannered and polite for a robber 'nothing at all like in the movies.' As a result, one newspaper even referred to me as a 'gentlemanly gangster.' When I was later arrested, these are the charges for which I was indicted by the grand jury (for the single drug store robbery described above):

- Two counts of aggravated robbery (my court-appointed attorney told me that this was because I took the money and the drugs).

- One count of kidnapping for each person who happened to be in the store during the robbery (according to the letter of the law, if a robber says 'freeze, this is a stick-up!' he is guilty of kidnapping anyone who freezes because in doing so they are restrained of their liberty).

- One count of drug theft.

- One count of felonious assault. (This charge was the result of one of the customers stating to the police and news reporters that when she realized the store was being robbed, she 'almost had a heart attack.' The fact that this was 
merely a figure of speech, as well as the fact that this same customer told the police and reporters that I was 'awfully polite for a robber,' was totally irrelevant, according to the law.)

- One count of having weapons while under disability.

- Four counts of possession of criminal tools (a paper bag, a piece of paper and the like).

My court-appointed attorney assured me that although it wasn't fair, I could and would be convicted for every charge listed above because technically I was guilty of each charge even though the only crime I knowingly and intentionally committed was a single robbery of a drug store. He told me that if I would cooperate with the prosecutor by pleading guilty to just a couple of the charges, he could arrange to have the rest of the charges dropped. He told me that if I would not cooperate in this matter, he would be totally powerless to defend me, and that, if I took the case to trial, I could expect to be convicted and sentenced to prison for each charge. He pulled out his calculator, pushed a few buttons, shook his head in feigned sorrow, and proclaimed, 'I think we had better cooperate with the prosecutor, because we're looking at 59 to 195 years in prison, if we try to take a stand at trial' (as if we were going to do the time together).

Because I was young, scared, uneducated, and inexperienced in the workings of the criminal justice system and the law, I believed him. I also believed that if the prosecutor could be so dishonest as to have me indicted for all those charges knowing that the only crime that was committed was one armed robbery, and that, if the very attorney appointed to defend me was actually sitting here telling me to do whatever the prosecutor wants me to do and to be thankful for it, then certainly I couldn't expect anything that would resemble a fair trial. I pled guilty to one count of aggravated robbery and one count of drug theft: two convictions for the single crime - double jeopardy. The sentences were run concurrent - seven to twenty-five years.

Of the 612 prisoners whose cases were reviewed in my survey:

- $100 \%$ pled guilty or no contest to the charges for which they were sentenced to prison.

- $41 \%$ assert that they are innocent, and that they were coerced into pleading guilty or no_contest because their court-appointed lawyers refused to investigate the charges or prepare a real defense, choosing instead to 'encourage' the prisoner to 'cooperate with the prosecutor.'

- $8 \%$ said that they did commit the crimes for which they pled guilty or no contest, and that they got a fair deal.

- $51 \%$ stated that although they were guilty of some of the crimes they pled guilty or no contest to, they were not guilty of all the crimes they pled guilty or no contest to (this is the category I fall into). 
- My review of the indictments and all applicable law indicates that $88 \%$ were over-indicted as I was.

- $100 \%$ were instructed by their court-appointed lawyers to state for the record (in the courtroom) that no plea bargains were made in their cases, and that they were pleading guilty or no contest of their own free will.

- $53 \%$ received stiffer sentences than they were promised in return for their pleas of guilty or no contest.

The overwhelming majority of prisoners in the United States are victims of coercive 'plea bargaining' and have never experienced a trial. As Caulfield tells us:

The prosecutor basically has unchecked discretion in relation to plea bargaining and charge reduction. As noted by Nissman and Hagan (1982), the prosecutor has sole discretion in charging decisions and only in exceptional cases will these decisions be judicially reviewed (Caulfield 1989: 236).

In National Prosecution Standards (National District Attorneys Association 1977), it states that what charges and how many charges will be filed in any given case is at the sole discretion of the prosecutor. Although those standards do include guidelines which state that a record of the charging decision should be made in each case and should be maintained in order to verify adherence to the prosecutor's guidelines, if one looks further, s/he will note that this record shall be available for office use only and should not be made available for outside use or dissemination. In other words, a record should be maintained, but it should not be subject to public scrutiny. If not subject to public scrutiny, these records maintain the same secrecy that exists without them (ibid.: 237).

Caulfield (1989) also points out that some would argue that there are processes built into the system to prevent the misuse of prosecutorial discretion, such as the grand jury's review of indictments. However, she observes that:

A determination of misused discretion as applied to the charging decision is not likely to be made by the grand jury even given information that supports a charge of misuse. To the contrary, as Campbell (1973) noted: 'At its best, the grand jury today operates as a sounding board for the predetermined conclusions of the prosecuting official' (p. 178). While the history of the grand jury instructs us that.one of its functions is that of 'the people's watchdog,' that is, to seek out and disclose governmental abuse or detect areas in need of legislative reform ... it is difficult to regard this as true if the grand jury is, in fact, simply a tool for the prosecution (Caulfield 1989: 235).

Indeed, in the face of evidence of discretionary abuse in the form of multiple charges against a defendant for an alleged single offense in order to coerce a 'plea bargain,' the prosecutor may easily manipulate the grand jury by playing on that long-instilled mythical assumption 
that 'the defendant will not be convicted by the trial jury unless he is, indeed, guilty, for this is America, where there is Liberty and Justice for All!' And if this reasoning alone can not impel the grand jury to agree with the indictments, the prosecutor has at his fingertips many more 'tools of the trade' with which to utilize his manipulative expertise. For example, if the grand jury in my Cleveland case was not quite convinced that it would be fair and just to issue 195 years worth of indictments against me for the single robbery I committed (which at that time carried a maximum of twenty-five years), the prosecutor could have simply pointed out to the grand jurors that their duly elected state legislators, who happen to be 'experts' in this very type of thing, have already carefully considered this very matter, and have determined, in their 'expert' judgment, that coercive plea bargaining and multiple indictments for single offenses - and in some cases for no offenses at all - are in the public interest. As proof, he could open Ohio's criminal law book and show them the passage that reads:

[T]his section shall not be construed to prohibit a prosecutor [from] ... offering or agreeing to dismiss, or dismissing one or more charges pending against an accused ... [or] offering or agreeing to grant immunity from prosecution ... [i]n return for a plea of guilty to one or more offenses charged or to one or more other or lesser offenses, or in return for the testimony of the accused [against one or more other persons] ... (Section 2905.12 of the Ohio Revised Code).

For those who would argue that these 'plea bargaining' tactics are not coercive, take note that the above citation is located right in the middle of the criminal statute entitled 'Coercion,' which makes it a crime for everyone but prosecutors to 'threaten any calumny against any person ... institute or threaten any criminal proceedings against any person ... [or] take or withhold, or threaten to take or withhold, or cause or threaten to cause official action to be taken or withheld ... with purpose to coerce another into taking or refraining from action concerning which he has a legal freedom of choice,' such as the legal freedom of choice to be considered innocent until proven guilty in a fair trial by jury.

Others may argue that it just does not make sense that a truly innocent person would plead guilty or no contest to a crimes/he did not commit. However, consider the circumstances. You have no money, and therefore, you must rely on a court-appointed attorney whose only energy expended on the case has been utilized in an effort to convince you to plead guilty or no contest. Court-appointed attorneys have a clear motivation for this action, because they receive the same wage regardless of the outcome of the case; therefore, they make more money in less time if they can convince their client to plead guilty or no contest. In this way, they do not have to conduct an investigation or prepare a defense. You are informed that other county-jail prisoners, whom you have 
never met in your life, have agreed to testify that you told them that you committed the crime: Of course, this arrangement is their 'plea bargain' in their own criminal charges, for which they may or may not be guilty. Their charges will be dropped in exchange for their testimony against you, the unco-operative one. And you have no alibi witnesses because you were at home alone at the time of the alleged offense. And if you have a criminal record, you know it will weigh heavily against you in the minds of the jurors - especially if your record is based on a plea of guilty or no contest, which the unknowing jurors, the manipulated jurors, will consider as conclusive proof that you are, in fact, a common criminal, an habitual criminal, a repeat offender.

Under these circumstances, who is going to believe you are innocent? What are the odds? Would you try your luck at a trial like you would try your luck at a lottery, knowing that, if you do not win, you may spend the rest of your natural life in a cage, just as your court-appointed attorney has assured you? Or would you prefer to plead guilty or no contest to a charge or two, knowing that, if this is the choice you make, you have almost a $100 \%$ chance of seeing the free world again sometime before you die? Forty-one percent of the prisoners in my survey who pled guilty or no contest assert that they are innocent. How can we be sure? I believe most of them after having read the documents in their cases - documents which are kept secret from the public as a matter of governmental policy as set forth in the National Prosecution Standards (1977).

Even if the grand jury were to function as 'the people's watchdog,' it is impossible for them to consider that which is with held from them. Do you suppose, for example, that the prosecutor responsible for coercing (or 'enticing' with a carrot of immunity) someone to give perjured testimony against a defendant, the prosecutor responsible for withholding evidence which points to a defendant's innocence, and the prosecutor responsible for other conduct aimed at securing the conviction and imprisonment (or execution) of a defendant he knows to be innocent is likely to exercise his discretion in good faith when the defendant he has railroaded to prison or death row attempts to press criminal charges against him for those actions? Do you suppose the prosecutor will act in good faith by presenting such charges and evidence against himself (or those he has conspired with) to the grand jury, knowing that he has the 'legitimate' authority, the absolute discretion, to throw such charges and evidence into the incinerator? Since it is solely up to the prosecutor what will be presented or withheld from the grand jury, it is not likely that the grand jury will ever see such evidence.

As a case in point, I had a cell mate, Jesus Zamora, who is serving a life sentence for a crime I am convinced never occurred. His conviction 
(by a trial jury) was obtained on the basis of perjured testimony by every state witness who testified. We have solid evidence that absolutely every witness perjured, including a police chief who testified that he had arrested Jesus in the past for a crime that Jesus was never arrested for. We also have solid evidence that the court-appointed attorney, the prosecutor and the presiding judge all had knowledge (during the trial) that the state's star witness was committing perjury. As indicated in the trial transcripts (State of Ohio v. Jesus Zamora, Case Number 84-CR-090, Wood County Court of Common Pleas, Ohio), after the prosecutor presented all the state's evidence, the state rested its case, and it was now time for the defense to begin presenting its case.

At this point, the court-appointed attorney stated to the judge, 'Your Honor, I believe Mr. Zamora would have a request to the Court.' Zamora then stated that he wanted his court-appointed attorney dismissed from the case because the attorney had failed to conduct an investigation, he failed to call witnesses (or to even interview witnesses who had told him they wanted to testify on behalf of Zamora), he failed to do anything at all that Zamora asked him to do in order to prove his innocence, and Zamora could not do these things himself, because he was in jail pending trial and unable to afford bond. There was one witness in particular that Zamora wanted on the stand. That witness was subpoenaed by the prosecutor as a state's witness, but he left the courthouse before taking the stand because the prosecutor told him to leave. That witness could have proved Zamora's innocence. However, the court-appointed attorney stated to the judge, that he did not want to call this witness:

I feel that a large number of [the questions Zamora wants me to ask this witness] are irrelevant and other questions could bring out material that would reflect on Mr. Zamora's prior record. I am certainly not in a position where I am going to invest as much time into a case as I have and drop a bombshell on our own defense. So, if Mr. Zamora is willing and able to waive counsel at this point, and if he is willing to proceed in his own defense, I have no objection to that. Perhaps we can find out if [the man he wants called as a witness is still] available, but I am not at this juncture going to call him as a witness. If Mr. Zamora wants to proceed on his own behalf and ask the questions he has propounded to me for [the witness], so be it.

... I think it is certainly Mr. Zamora's desire that I withdraw and now it is my desire. If the court were forced to declare a mistrial, it is certainly not one caused by the prosecution and I think that alleviates the speedy trial statute from consideration in terms of a mistrial and that the state would have a reasonable time to retry the case. I apologize, but judge, I don't know how I can do a good job for a man facing two mandatory life sentences who basically called me a liar in front of the Court.

After a bit more arguing, the prosecutor stated to the judge: 
Your Honor, I realize that [defense counsel] is in a very difficult position, but so, I think, is the Court, and so is the State [never mind the guy facing two mandatory life sentences - there's nothing difficult about his situation]. We have gone through the entire trial, laid out all the cards we have, and we are at the point of giving instructions and closing. That is the point that this was brought to light. This is after the defendant has already seen what everybody has testified to and everything that has been presented. Now he is trying to get the Court to grant a mistrial and we [as in 'we the people'] respectfully ask that the Court not to do that. We have gone all the way through the trial and we are at the point of closing the case and I am sure [defense counsel] can continue in that regard and close the case regardless of whether a speedy trial is an issue. This is also regardless of whether we can retry this case. I don't think it should be retried. It has already been tried fairly and we should give it to the jury and let them decide.

The judge responded by noting that the defense had not yet begun to present its case, much less rested. The prosecutor's response to this was, 'I understand that, but from all indications there was to be no defense and I assume that is still the case' (emphasis added). The judge then turned to Zamora and asked, 'Mr. Zamora, are you requesting that you represent yourself in this case?' Realizing that he could not possibly represent himself (since he could not conduct an investigation from inside a jail cell) that he knew absolutely nothing about the law, and that he did not even possess a high-school education (rendering him hardly an effective opponent against an experienced prosecuting attorney and his many assistants), Zamora replied to the judge: 'No.' The judge then stated:

Well, whenever counsel for the defense takes a case, they take an obligation until they are relieved. The Court feels that it cannot relieve counsel at this juncture of the trial of such a critical nature.

Note that all of this occurred in the courtroom while the jury was out to lunch, as is often the case. The jury had noidea that any of this had taken place. When the jury returned, the defense counsel rested his case. The prosecutor was certainly right: there was absolutely no defense presented to the jury, so I have difficulty perceiving what the courtappointed lawyer was imagining when he stated that he was not going to 'drop a bombshell on our own defense.' What defense?

Meanwhile, Zamora is disappointed that he refused to accept the offered 'plea bargain' that would have resulted in his being jailed for a maximum of six months. He had refused to plead guilty to anything because he was guilty of nothing, and because he believed, like so many others who have been deceived about American 'liberty and justice for all,' that the jury would see the truth and find him innocent. The Ohio Supreme Court feels that the perjury is of no significance, and that the judge's, the prosecutor's, and the court-appointed lawyer's knowing and willful withholding of evidence from the trial jury is of no signifi- 
cance. The mere fact that the court-appointed attorney is a member of the bar is conclusive evidence of his competence. For this reason, the claim of ineffective assistance of counsel would not be considered on appeal. Zamora gave up on his appeals. He is absolutely certain that there will never be justice in his case, because his case is no different than the cases of so many other prisoners he lives with.

Several years ago I helped Zamora prepare some criminal complaints against various people involved in securing his conviction through the use of perjury and fabricated evidence. The complaints contained solid evidence in support of his allegations of perjury and conspiracy. The prosecutor never did present the criminal charges or evidence to the grand jury. But, of course, we did not really expect for him to prosecute himself or those he conspired with to put Jesus, an innocent man, in prison for the rest of his life.

But why would a prosecutor, a judge, a court-appointed attorney, or any politician bent on building more prisons want to fill them with people, regardless of their guilt or innocence? What can the motivation of these officials possibly be? Well, I must confess, I do not have all the answers - but I think I have some of them. Perhaps, the answers to that question can be the focus of a future edition of this journal. Perhaps some of the answers are implicated in the following essays. In the meantime, I think that it would be interesting to find out how judges, prosecutors, court-appointed attorneys, and politicians bent on building and filling prisons are connected to stock-holders of the businesses that are making immense (i.e. multi-billion dollar) profits from the slave labor performed by prisoners. For contrary to common belief, the Thirteenth Amendment to the United States Constitution did not abolish slavery; it merely transformed it:

Neither slavery nor involuntary servitude, except as punishment for crime whereof the party shall have [pled guilty or no contest or] been duly convicted, shall exist within the United States, or any place subject to their jurisdiction.

Of course, wealth is but one motive for putting people in prison. An even more fundamental motive is control. I am reminded of a dream I had not long ago. In that dream, I saw the Persian Gulf War, and I saw people in the US military who refused to take part in the war because their consciences would not allow them to slaughter their fellow human beings for George Bush and his oil-baron buddies. I saw a lot of behavior modification and control techniques, not unlike those employed by the US military to crush the resistance of dissenters, and I realized that there is really no difference between the US military and the amerikan criminal Just-Us Cyst' $m$, and that they are two interrelated components of the machinery of the power elite used to control everyone, everywhere - domestically and abroad. 
In 1989, a medical doctor in the Army Reserves, David Wiggins, filed for a discharge as a Conscientious Objector (CO). Although everyone in his chain of command testified to his sincerity, his claim was denied by the Pentagon in August 1990. He went on a hunger strike to protest Desert Shield, even as he was forcibly deployed to the Gulf. In Saudi Arabia, he made numerous attempts to submit his resignation as an army doctor, but his resignation was not accepted. Finally, as the bombs began to drop on Iraq, he removed his army uniform to dissociate himself from the war, and he walked into the streets of Riyadh. He was court-marshaled in Saudi Arabia and imprisoned. He was eventually given a dishonorable discharge and a $\$ 25,000$ fine.

Many army and marine reservists, and soldiers who declared themselves conscientiously opposed to the war, were beaten, hand-cuffed, placed in leg irons, and forcibly shipped to Saudi Arabia where they were dropped into the middle of a combat zone by commanding officers who knew they would not fire a weapon.

Many COs today occupy amerika's prisons, having received stiffer sentences than people who went AWOL for reasons that have nothing to do with conscience. Said Harvey Hensley while starting his two-year sentence for refusing to kill people: "The military tried to make an example of conscientious objectors in this war because it fears dissent. COs were treated worse than people who simply went AWOL.' Indeed they were. As Naomi Thiers writes:

Not surprisingly, the military is trying to downplay the resistance. Stephanie Atkinson [a CO] said she and other resisters were pressured not to talk to the media. They deny that they put a media gag on me, but that's what it was. I was told that if I talked to the press I'd be disobeying a direct order and it would make it very difficult for my case.

The military also tried to isolate resisters from other soldiers ... Atkinson recalled that when local peace groups held a demonstration against her confinement at Fort Knox, the base was put on lockdown (meaning soldiers could not leave) so that GIs would not come in contact with peace activists (Thiers 1991: 27).

Imprisonment and the use of plea-bargaining to obtain convictions is also related to the US military's intentions for the New World Order. According to a 46-page policy statement developed by the Defense Department in conjunction with the National Security Council, George Bush, and his senior national security advisors, the US political and military mission, in simple language that we can all understand, is to become the planet's dictator. It will militarily crush any nation or group of nations for 'challenging our leadership or seeking to overturn the established political and economic order.' In a March 1992 article in the New York Times, Patrick E. Tyler considers this policy : 
With its focus on benevolent domination by one power, the document rejects collective internationalism, the strategy that emerged from World War II when the Allies sought to form a United Nations that could mediate disputes and police outbreaks of violence (emphasis added).

The US apparently intends on resolving all such disputes and policing all outbreaks of violence unilaterally, without any enforceable input from the other nations of the world. This would effectually strip all nations on the planet of their nation-state status, since there will no longer be even a pretext of self-determination, for the very right of selfdetermination means the right of the people of each nation to determine their political and economic status and structure without external influence. Such autonomy can not be realized by any nation or group of nations on the planet if the US succeeds in its mission to dictate 'the established political and economic order' of the world.

Of course, those who drafted this US policy realize that the masses, domestically and abroad, who are increasingly homeless and starving as a result of the 'established political and economic order,' will increasingly express their dissent. The construction of ever more control unit prisons is one means of controlling the masses in the United States. The practice of railroading dissenters and the victims of US policy into those prisons (e.g. through coercive plea-bargaining) is the only 'legitimate' way to silence the voices of the innocent masses. Another way of silencing those voices are the recommendations provided by the policy that include the Bush administration's proposal to support a 1,600,000 person military over the next five years at a cost of approximately $\$ 1,200,000,000,000$ - 'benevolent domination,' indeed!

In conclusion, I want to tell you a little story. Today I accompanied a friend of mine, a black woman, to the courthouse in Cincinnati because her brother was going to trial for an alleged assault. Two days ago, my friend called her brother's court-appointed lawyer to inquire about the case. He told her it was none of her business. When we got to the courtroom, the attorney introduced himself to me, my friend, and two other people, one of whom was a doctor, all of whom were there to support the brother. He told us that the agenda was to work out a plea bargain for the brother so that he would only have to spend, perhaps, two years in prison instead of the decade he could expect if he did not plead guilty or no contest. One of us asked the attorney how badly the victim was allegedly beaten by my friend's brother. The attorney replied: 'I heard the victim was severely beaten, but I don't know to what extent any injuries were incurred. I don't know if there were any broken bones or anything. Do any of you know?' I confronted the attorney. I expressed a deep concern with the fact that he did not know the extent, if any, of the alleged victim's injuries. I asked if he had done anything to investigate on behalf of his client, and if so, what had he 
done? I asked him 'how can you suggest that he plead guilty to something when you don't even know what, if anything, he has done?'

The attorney indignantly proclaimed that he was not on trial, that he would not be interrogated, and that he did not have to answer my questions. I replied 'that's because you are unable to answer my questions, Mister. You have not conducted the investigation which you are lawfully required to conduct in this case. Are you planning on railroading my brother to prison?' He blurted out, trembling in apparent fear: 'Hey, you take a hike, Pal!' He stumbled over to the other end of the courtroom and went into a closed conference with the judge (whom he had indicated is a good friend of his) and some other courtroom officials.

When they returned from the judge's chambers, one of the assistant prosecutors and two huge police officers attempted to intimidate me by talking with each other in a voice loud enough for me to hear across the courtroom. Their conversation implied that I had committed the crime of 'menacing.' I am not easily intimidated, however, and I made them understand that I was organizing courtroom witnesses for an appeal on the grounds of ineffective assistance of counsel. Everyone who heard the statement of the court-appointed attorney (that he did not know the extent of the victim's injuries) was in agreement that he was railroading our brother to prison.

The attorney and all the courtroom officials agreed too, apparently. There was no plea of guilty or no contest in that courtroom, and our bro walked out of jail and he is riding in a car with his sister to Columbus as I write this.

The point is: they can only do it to us if we let them.

The author wishes to thank Naomi Thiers, the National Interreligious Service Board for Conscientious Objectors, the War Resistance League, and the Central Committee for Conscientious Objectors for providing the information in this essay relating to the Persian Gulf War resistance and prisoners of conscience. I would also like to note that for those government agents who will undoubtedly question the validity of my claim that there are many innocent people in the prisons of the United States, and that they are being placed there knowingly and willingly by government agents, I challenge them to produce evidence that will refute my claim. This paper is extracted from one of the chapters of a book soon to be published (Reed, et al., in press), which is being nominated for awards bestowed annually by the American Society of Criminology, Division on Critical Criminology, the Academy of Criminal Justice Sciences, the Society for the Study of Social Problems (SSSP), and the SSSPs Division on Crime and Juvenile Delinquency. 


\section{REFERENCES}

Campbell, W.J. 1973. 'Eliminate the Grand Jury.' The Journal of Criminal Law and Criminology, 64 (2): 174-182

Caulfield, S.L. 1989. 'Life or Death Decisions: Prosecutorial Power v. Equality of Justice.' Journal of Contemporary Criminal Justice, 5 (4): 233-247

National District Attorneys Association. 1977. National Prosecution Standards. Chicago: National District Attorneys Association

Nissman, D.M., and E. Hagan. 1982. The Prosecution Function. Lexington, MA: Lexington Books

Reed, L.R. 1993. The American Indian in the White Man's Prisons: A Story of Genocide. Villa Hills, KY: Native American Prisoners' Rehabilitation Research Project (in press)

Spence, G. 1989. With Justice For None, Destroying an American Myth. New York: Penguin Group

Thiers, N. 1991. 'Coercion of Conscience.' The Other Side, (July-August): 22-30 